\title{
Gamma Irradiation Up-regulates Expression of B Cell Differentiation Molecule CD23 by NF-kB Activation
}

\author{
Hyun-Sook Rho, Soon-Suk Park and Choong-Eun Lee* \\ Laboratory of Immunology, Department of Biological Science, Sungkyunkwan University, Suwon 440-746, Korea
}

Received 26 January 2004, Accepted 30 January 2004

\begin{abstract}
Gamma irradiation $(\gamma$-IR) is reported to have diverse effects on immune cell apoptosis, survival and differentiation. In the present study, the immunomodulatory effect of a low dose $\gamma$ IR (5 10 Gy) was investigated, focusing on the role of NF- $\mathrm{kB}$ in the induction of the $B$ cell differentiation molecule, CD23/ FceRII. In the human B cell line Ramos, $\gamma$-IR not only induced CD23 expression, but also augmented the IL-4induced surface CD23 levels. While $\gamma$-IR did not cause STAT6 activation in these cells, it did induce both DNA binding and the transcriptional activity of NF- $\mathrm{KB}$ in the IKB degradation-dependent manner. It was subsequently found that different NF- $\kappa B$ regulating signals modulated the $\gamma$-IRor IL-4-induced CD23 expression. Inhibitors of NF- $\mathrm{KB}$ activation, such as PDTC and MG132, suppressed the $\gamma$-IRmediated CD23 expression. In contrast, Ras, which potentiates $\gamma$-IR-induced NF- $\kappa B$ activity in these cells, further augmented the $\gamma$-IR- or IL-4-induced CD23 levels, The induction of NF- $\mathrm{KB}$ activation and the subsequent upregulation of CD23 expression by $\boldsymbol{\gamma}$-IR were also observed in monocytic cells. These results suggest that $\boldsymbol{\gamma}$-IR, at specific dosages, can modulate immune cell differentiation through the activation of NF- $\mathrm{kB}$, and this potentially affects the immune inflammatory response that is mediated by cytokines.
\end{abstract}

Keywords: Allergic inflammation, B cell differentiation, CD23/FceRII, Gamma-irradiation, NF- $\mathrm{BB}$

\section{Introduction}

Ionizing radiation induces diverse effects on cell survival, apoptosis, proliferation and differentiation depending on the dosage and target cell type (Jonathane et al., 1999). High

*To whom correspondence should be addressed.

Tel : 82-31-290-7006; Fax: 82-31-290-7015

E-mail: celee@skku.ac.kr dosage of gamma-irradiation $(\gamma$-IR) often results in massive DNA damage that involves double-strand breaks and the subsequent cell death. A low dose of $\gamma$-IR induces reactive oxygen species and the activation of specific intracellular signaling pathways and transcription factors leading to proliferation and differentiation of target cells (Kasid et al., 1996; Lander, 1997; Finkel, 1998). So it is that $\gamma$-IR has been reported to suppress or modulate immune response due to its variable effects on immune cell survival and differentiation (Shanker et al., 1999; Zhu et al., 1999).

$\mathrm{NF}-\kappa \mathrm{B}$ is a major signaling molecule activated when the cell receives a dose of stressful radiation. It is involved in the regulation of immune cell survival as well as immune inflammatory response (Brach et al., 1991; Gosh et al., 1998; Hatada et al., 2000; Karin and Lin, 2002). Although a number of studies have established the role of NF- $\mathrm{KB}$ as a survival factor during the stress response induced upon ionizing radiation, function of $\mathrm{NF}-\kappa \mathrm{B}$ as a key transcription factor regulating specific gene expression and immune cell differentiation upon $\gamma$-IR exposure has not been widely investigated. In addition, the upstream signals of NF- $\kappa \mathrm{B}$ activation evoked by $\gamma$-IR remain elusive and they seem to vary depending on the type of immune cells analyzed (Schreck et al., 1991; Brennan and O'Neil, 1995; Finco et al., 1997; Reddy et al., 2000).

In the present study, we investigated the immunomodulatory effects of $\gamma$-IR focusing on the role of NF- $\kappa B$ activation in CD23 expression of type II IgE receptor (FceR II). CD23/ FceR II, expressed on B cells and monocytes, is mainly induced by IL-4 through the Jak1/STAT6 pathway (Hou et al., 1994; Mikita et al., 1996; Nakanishi et al., 1996). It is also known as a marker of B cell differentiation, IgE production, and a key adhesion molecule involved in allergic inflammation (Sarfati ans Delespesse, 1988; Flores-Romo et $a l ., 1993)$. Here, we report that $\gamma$-IR (5 10 Gy) alone induces CD23 gene expression and up-regulates IL-4-induced CD23 levels in B cells and in the monocytic cell lines. Our data indicate that such modulatory effects of $\gamma$-IR on CD23 expression are mediated by NF- $\mathrm{KB}$ activation. We also present 
evidence that $\gamma$-IR-induced NF- $\kappa B$ activation proceeds via $\mathrm{I} \kappa \mathrm{B}$ degradation and the proteosome-dependent pathways, and is subject to further upregulation by oncogenic Ras. We employed CD23 as a target molecule, and this current study has partially elucidated the activation mechanism of NF- $\kappa B$ by $\gamma$-IR in human B cells. These results have suggested that there is a role for NF- $\kappa B$ in $\gamma$-IR-induced $B$ cell differentiation and allergic inflammation.

\section{Materials and Methods}

Immune cell stimulation and $\boldsymbol{\gamma}$-irradiation Ramos B cells and U937 monocytic cells were maintained and cultured in complete RPMI media (GIBCO, Grand Island, USA) at $37^{\circ} \mathrm{C}$ with $5 \% \mathrm{CO}_{2}$.

A
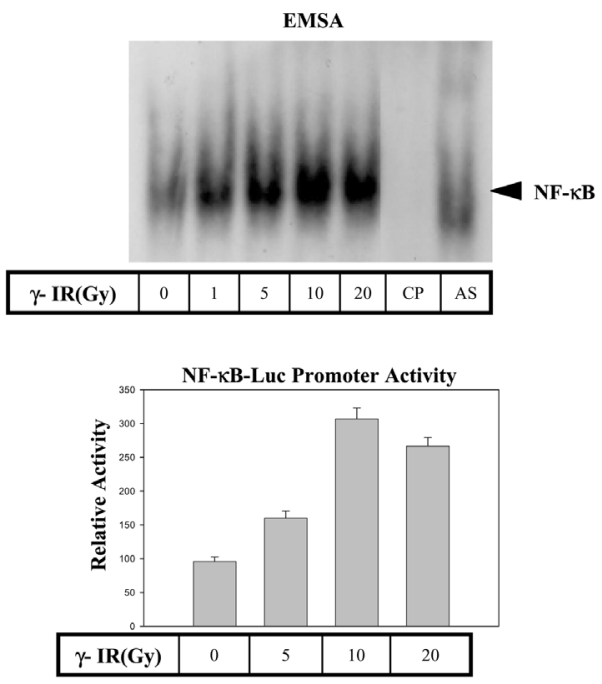

C

EMSA
Tonsilar mononuclear cells were isolated from freshly excised tonsils using Ficoll-Hypaque $(\mathrm{d}=1.077$, Sigma, St Louis, USA) as described (So et al, 2000). The cells were irradiated at room temperature with a ${ }^{137} \mathrm{Cs} \gamma$-source at a dose rate of $5.66 \mathrm{~Gy} / \mathrm{min}$ using an IBL 437C type $\mathrm{H}$ irradiator (CIS Biointernational, Nice France) at various dosages. After irradiation, cells were incubated at $37^{\circ} \mathrm{C}$ for various time periods. Where indicated, the cells were treated with different inhibitors for $1 \mathrm{~h}$ prior to stimulation with $\gamma$-IR.

Northern blot After exposing the cells to $\gamma$-IR or IL-4 (R + D System, Minneapolis, USA) for $12 \mathrm{~h}$, the total cytoplasmic RNAs were isolated. They were separated on a $1 \%$ agarose gel, transferred to nylon membrane and then hybridized with a full-length $\left[\alpha-{ }^{32} \mathrm{P}\right]-$ labelled cDNA probe of CD23 as previously described (So et al., 2002).
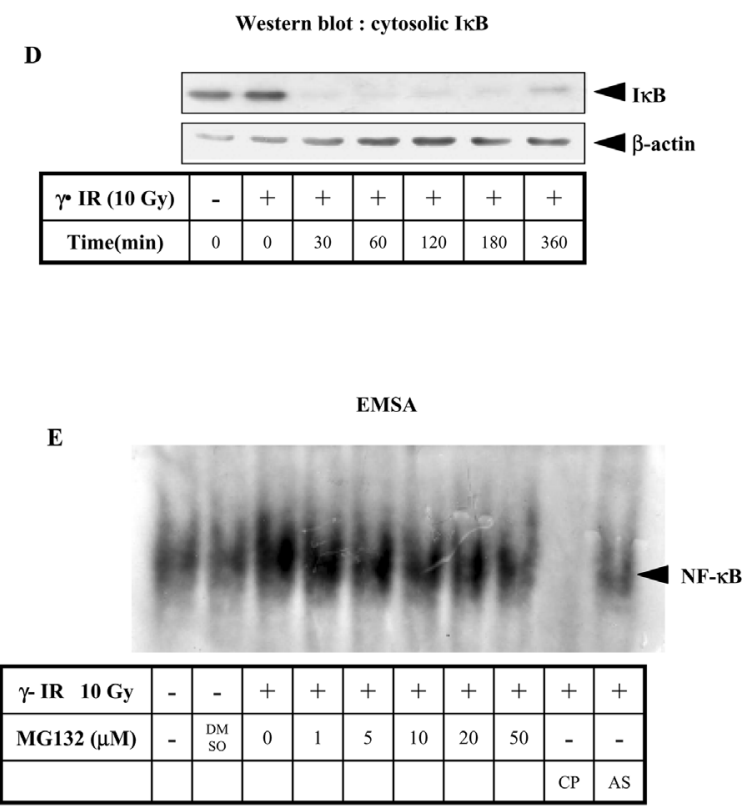

\begin{tabular}{|c|c|c|c|c|c|c|c|c|c|}
\hline$\gamma$ - IR(10 Gy) & - & + & + & + & + & + & + & + & + \\
\hline Time(min) & 0 & 0 & 60 & 120 & 180 & 360 & 720 & 120 & 120 \\
\hline & & & & & & & & CP & AS \\
\hline
\end{tabular}

Fig. 1. Mechanisms of NF- $\mathrm{BB}$ activation by $\gamma$-irradiation in B cells. (A) Ramos B cells $\left(1 \times 10^{6}\right.$ cells $\left./ \mathrm{ml}\right)$ were exposed to varying doses of $\gamma$-irradiation. After $1 \mathrm{~h}$, cells were harvested and their nuclear extracts were prepared. EMSA was performed using $10 \mu \mathrm{g}$ of nuclear proteins and $1 \mathrm{ng}$ of $\left[{ }^{32} \mathrm{P}\right]$-labeled oligonucleotide containing a NF- $\kappa \mathrm{B}$ sequence as a probe. For competition $(\mathrm{CP})$ or antibody supershift (AS) assays, a 100 fold molar excess of the unlabeled probe or anti-NF- $\kappa B$ antibody, respectively, was preincubated with the extracts for $30 \mathrm{~min}$ prior to the addition of the labeled probe. (B) Ramos B cells $\left(2 \times 10^{7}\right.$ cells) were transiently transfected with $10 \mu \mathrm{g}$ of NF$\mathrm{\kappa B}$ promoter luciferase reporter plasmid by electroporation. After transfection, cells were allowed to recover for $24 \mathrm{~h}$ and then they were exposed to $\gamma$-irradiation at various dosages as indicated. Total lysates were prepared and the luciferase activity was measured. Each value represents the mean \pm S.D. of three independent determinations. (C) B cells were exposed to $\gamma$-irradiation (10 Gy) for various time periods as indicated. Nuclear extracts were incubated with the $\left[{ }^{32} \mathrm{P}\right]$-labeled NF- $\kappa \mathrm{B}$ probe, as in panel A. (D) B cells $\left(1 \times 10^{6}\right.$ cells/ $\mathrm{ml}$ ) were exposed to $\gamma$-irradiation $(10 \mathrm{~Gy})$ for various time periods as indicated. The cells were then harvested and their cytoplasmic extracts were prepared and analyzed by Western blot using anti-IкB antibodies. The membrane was then stripped and re-probed with $\beta$ actin antibodies for a control. (E) B cells $\left(0.5 \times 10^{7}\right.$ cells/well) were pretreated with varying concentrations of a proteasome inhibitor MG-132 for $1 \mathrm{~h}$ and then exposed to $\gamma$-irradiation (10 Gy). After a $1 \mathrm{~h}$ culture, nuclear extracts were prepared and EMSA was performed as in panel A. 
Flow cytometry The expression of surface CD23/FceR II was analyzed using a FACSCalibur (Becton Dickinson, Mountain View, USA) by staining the cultured cells with anti-human CD23 $\mathrm{mAb}(\mathrm{IgG} 1)-\mathrm{PE}$ conjugate after a $24 \mathrm{~h}$ exposure to IL- 4 or $\gamma$-IR. Isotype-matched antibodies (mouse IgG1) were used as a control to stain the cells as was described (Kim et al., 2003). Surface CD23 levels were expressed as relative means of the fluorescence intensities (MFI).

Electrophoretic mobility shift assay (EMSA) Nuclear extracts were prepared after the cells had been exposed to $\gamma$-IR or IL-4 for the indicated durations. The NFKB oligomer sequence present in the $\mathrm{CD} 23 \mathrm{~b}$ promoter was labeled with $\left[\alpha-{ }^{32} \mathrm{P}\right] \mathrm{dCTP}$ and incubated with extracts in the binding buffer (Kim et al., 2003). The mobility of the oligomer was then analyzed by a 4 PAGE in $0.5 \%$ TBE buffer.

Transient transfection Ramos B cells were transfected with the control vector, daRas (V12), and/or the NFKB-Luc reporter plasmid using an electroporator according to the manufacturer's instructions (So et al., 2001). After transfection, cells were allowed to recover for 24 to 48 hours, and then they were stimulated with IL-4 and /or $\gamma$-IR.

A
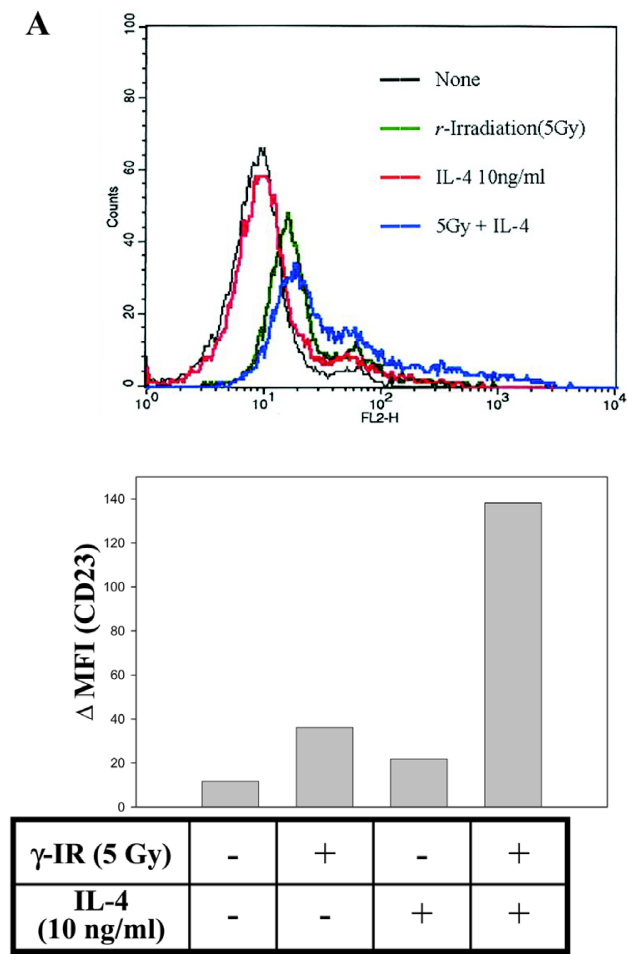

Western blot The total lysates were prepared and subjected to immunoblotting with polyclonal anti-phospho STAT6 or antiSTAT6 Abs (Upstate Biotechnologies Inc, Lake Placid, USA). Cytosolic and nuclear lysates were also prepared and these were subjected to immunoblotting with monoclonal anti-NFkB or antiIkB Abs, using an ECL system as described (Ozdener et al., 2002). Where indicated, histone or b-actin antibodies were used as a loading control.

Luciferase assay After $4 \mathrm{~h}$ of stimulating the transfected cells with IL-4 or $\gamma$-IR, the cell extracts were prepared. Luciferase activities were then determined by using the luciferase assay kit (Promega, Madison, USA) as described (Lee et al., 2002). Each experiment was repeated several times, and each value represents a mean S.D. of three independent determinations.

\section{Results and Discussion}

$\gamma$-Irradiation is known to induce $\mathrm{NF}-\kappa \mathrm{B}$ activation in an array of diverse cell types including the immune cells (Brach et al.,

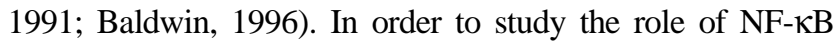
activation induced by $\gamma$-IR in B cell differentiation, the mode

B

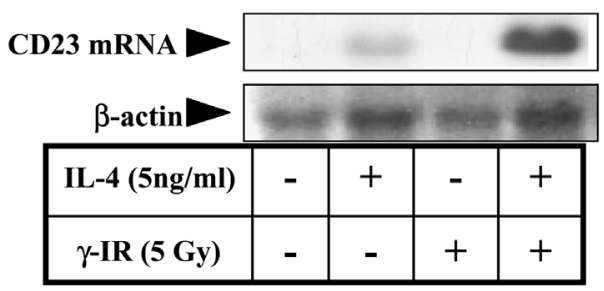

C

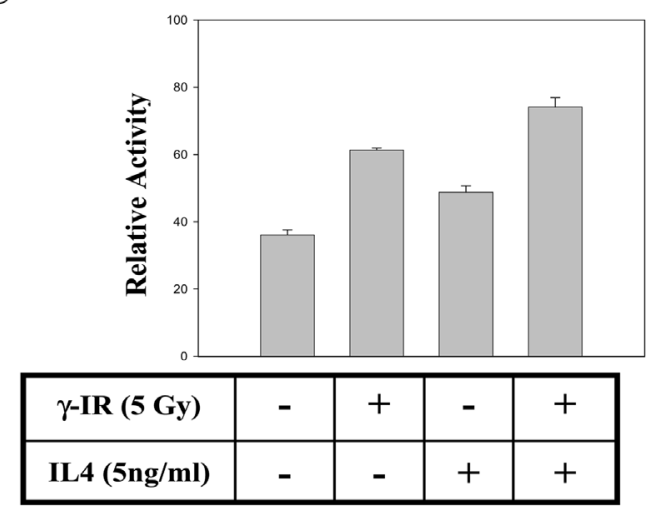

Fig. 2. The effect of $\gamma$-irradiation on CD23 expression. (A) Ramos B cells $\left(5 \times 10^{5} /\right.$ well $)$ were treated with media alone, $\gamma$-irradiation ( $5 \mathrm{~Gy})$, IL-4 $(10 \mathrm{ng} / \mathrm{ml})$, or IL-4 plus $\gamma$-irradiation. The cells were cultured for $24 \mathrm{~h}$, after which time the surface CD23 expression was measured by FACSCalibur analysis, as described in the text. A representative FACS histogram (Top), and the values for the relative fluorescence intensity (Bottom) are shown. (B) Tonsillar mononuclear cells $\left(1 \times 10^{7} /\right.$ well $)$ were treated with media alone, $\gamma$-irradiation ( $5 \mathrm{~Gy})$, IL-4 $(5 \mathrm{ng} / \mathrm{ml})$, or IL-4 plus $\gamma$-irradiation, and then cultured for $8 \mathrm{~h}$. The cells were collected and CD23 mRNA was analyzed for Northern blot. To normalize the amount of loaded RNA, the blot was reprobed with a $\beta$-actin probe. (C) Ramos B cells were transiently transfected with $10 \mu \mathrm{g}$ of NF- $\mathrm{KB}$ promoter luciferase reporter plasmid. The cells were allowed to recover for $24 \mathrm{~h}$ and then treated with media alone, IL-4 $(5 \mathrm{ng} / \mathrm{ml})$, or they exposed to $\gamma$-irradiation $(5 \mathrm{~Gy})$. After $4 \mathrm{~h}$, total lysates were prepared and luciferase activity was measured, as was done in Fig. 1B. The values represent a mean of three independent determinations. 
$\mathbf{A}$

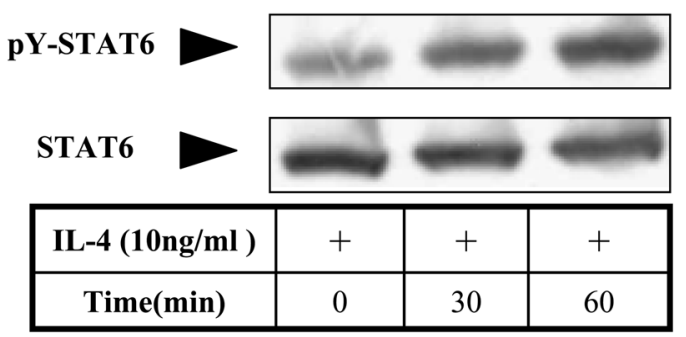

B

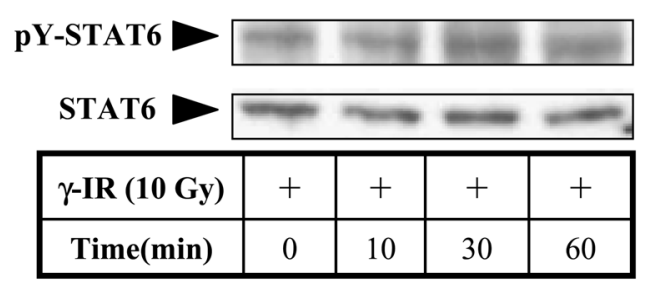

Fig. 3. The effect of $\gamma$-irradiation on STAT6 activation. (A) B cells $\left(1 \times 10^{6}\right.$ cells/) were treated with $\mathrm{IL}-4(10 \mathrm{ng} / \mathrm{ml})$ for various time periods as indicated. The cells were then harvested and nuclear extracts were prepared and analyzed by Western blot using anti-phosphotyrosine STAT6 antibodies. The membrane was then stripped and re-probed with anti-STAT6 antibodies for control. (B) B cells $\left(1 \times 10^{6}\right.$ cells/) were exposed to $\gamma$-irradiation $(10 \mathrm{~Gy})$ for various time periods as indicated. The nuclear extracts were prepared and analyzed by Western blot using antiphosphotyrosine STAT6 and then STAT6 antibodies, as was done in panel A.

of NF- $\kappa \mathrm{B}$ activation by $\gamma$-IR in B cells was first examined. Ramos B cells were exposed to a diverse range of $\gamma$-IR dosages, and the effect of $\gamma$-IR dose on NF- $\kappa \mathrm{B}$ activation was analyzed by employing an EMSA. While there was a significant induction of NF- $\mathrm{BB}$ activation observed upon exposure to 1 20 Gy of $\gamma$-IR, the maximum activation was noted at $10 \mathrm{~Gy}$ (Fig. 1A). The NF- $\mathrm{BB}$ reporter-luciferase assay confirmed the radiation dose-dependent induction of NF- $\kappa \mathrm{B}$ activity (Fig. 1B). The kinetics of NF- $\kappa \mathrm{B}$ activation by $\gamma$-IR showed that NF- $\kappa B$ is noticeably activated at $1 \mathrm{~h}$ after irradiation, and this is kinetically preceded by $\mathrm{I} \kappa \mathrm{B}$ degradation (Fig. 1C, D). This suggests that a $\gamma$-IR-generated signal induces IKB degradation, which leads to nuclear translocation and DNA-binding of the NF- $\mathrm{BB}$. There have been several reports that ionizing radiation, IL-1 or TNF-alpha causes, in certain cell types, NF- $\kappa \mathrm{B}$ activation and translocation that involves the direct phosphorylation of the NF- $\kappa \mathrm{B}$ complex without IKB degradation (Sakurai et al., 1999; Schmitz et al., 2001). Thus, in order to confirm the role of I $\mathrm{B}$ degradation in $\mathrm{NF}-\kappa \mathrm{B}$ activation for $\mathrm{B}$ cells, the effect of MG132, a proteosome inhibitor, was examined. As shown in Fig. 1E, the proteosome inhibitor MG132 suppressed the $\gamma$-IR-induced $\mathrm{NF}-\kappa \mathrm{B}$ activation in a dose-dependent manner, which further suggests that $\gamma$-IR-induced NF- $\mathrm{BB}$ activation in B cells occurs via the proteosome and $\mathrm{I} \kappa \mathrm{B}$ degradation-mediated pathways.

To investigate the role of NF- $\kappa \mathrm{B}$ activation in mediating $\gamma$ IR-induced immunomodulatory responses in these $\mathrm{B}$ cells, the effect of $\gamma$-IR on the expression of the B cell activation/ differentiation marker CD23 was analyzed. The type II IgE receptor, $\mathrm{CD} 23$, is known as a mediator of allergic responses, which is involved in IgE-dependent allergen uptake, processing, and antigen presentation to $\mathrm{T}$ cells, as well as in IgE production by B cells (Safarti and Delessepese, 1988; Kehry and Yamashita, 1989; Mudde et al., 1995).

While the induction of $\mathrm{CD} 23$ gene expression is mainly controlled by Th2 cytokines such as IL-4 or IL-13 via the STAT6-dependent pathways (Mikata et al., 1996; Nakanishi et al., 1996), NF-kB-mediated CD23 gene activation is thought to play an additive role in regulating CD23 expression in B cells and monocytes (Berberich et al., 1994; Kim et al., 1997). Indeed, an NF- $\mathrm{KB}$ site is present and adjacent to the STAT6 site in the $\mathrm{CD} 23 \mathrm{~b}$ promoter, and the functional interaction between STAT6 and NFkB has been demonstrated in the
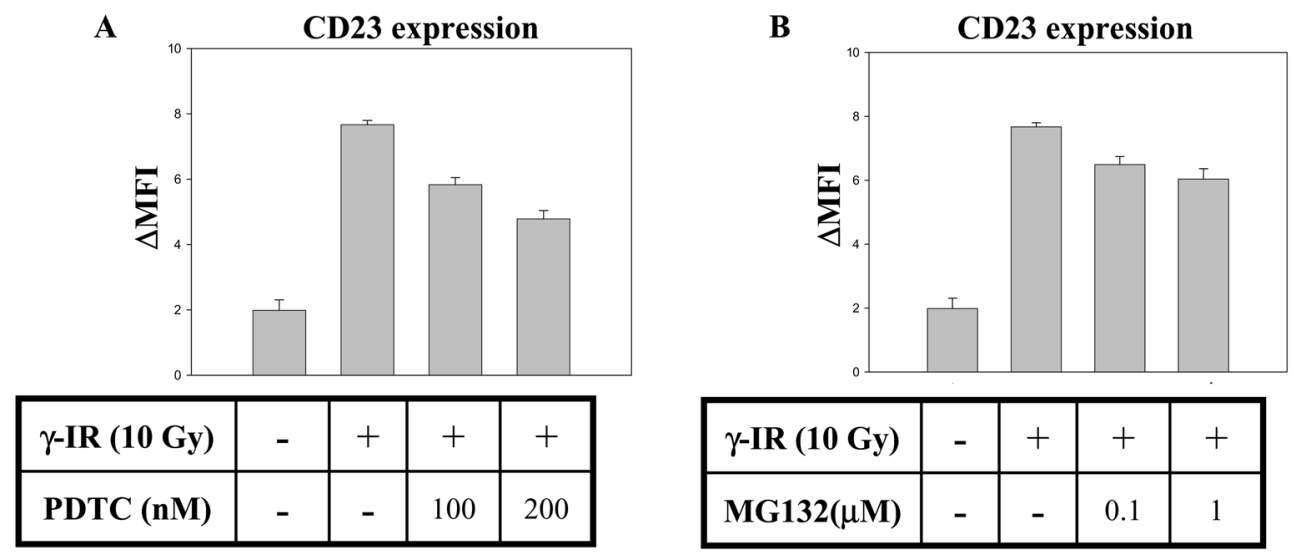

Fig. 4. The effects of NF- $\mathrm{BB}$ inhibitors on the $\gamma$-irradiation-induced CD23 expression: Suppressive effect of PDTC and MG-132. B cells were pretreated with PDTC (panel A) or MG-132 (panel B) for $1 \mathrm{~h}$ at the indicated doses. The cells were then exposed to $\gamma$-irradiation (10 Gy) and surface CD23 expression was measured after $24 \mathrm{~h}$ by a FACSCalibur analysis, as in Fig. 2A. Each value represents the mean \pm S.D. from triplicate samples. 


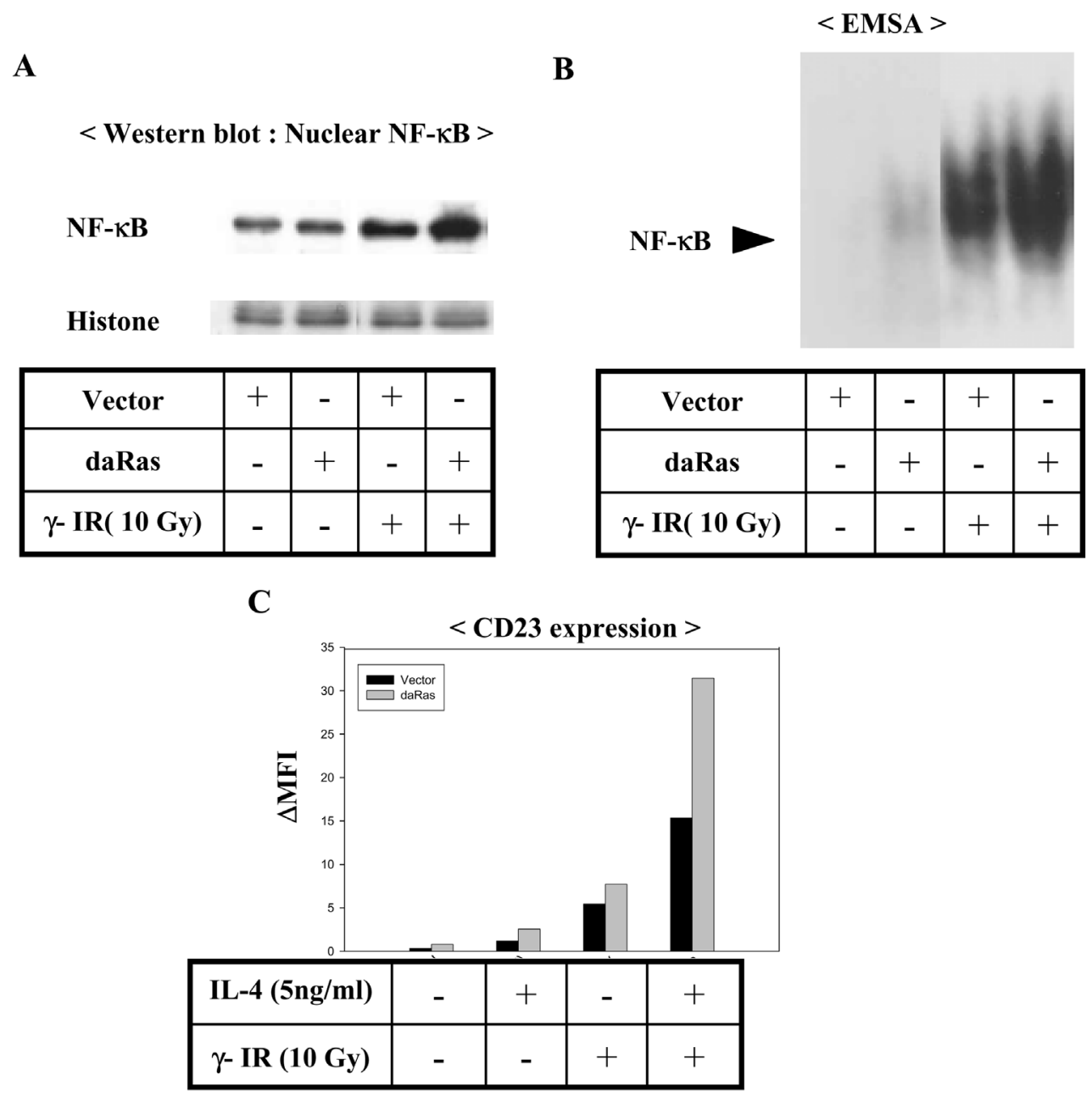

Fig. 5. The effect of Ras on NF- $\kappa B$ activation and CD23 expression. (A) Ramos B cells were transiently transfected with $10 \mu \mathrm{g}$ of vector alone (V) or dominant active Ras (daRas) using electroporation. After transfection, the cells were allowed to recover for $48 \mathrm{~h}$ and then they were exposed to $\gamma$-irradiation $(10 \mathrm{~Gy})$. At $1 \mathrm{~h}$ post-irradiation, the cells were harvested and a Western blot was performed with nuclear extracts to analyze the nuclear NF- $\mathrm{\kappa B}$ levels. The membrane was stripped and re-probed with anti-histone antibodies. (B) The nuclear extracts of transfected cells were also analyzed for NF- $\mathrm{BB}$ DNA binding activity by performing an EMSA. (C) Ramos B cells were transiently transfected with $10 \mu \mathrm{g}$ of vector alone (V) or dominant active Ras (daRas) using electroporation. After transfection, the cells were recovered for $48 \mathrm{~h}$ and then treated with media alone, $\gamma$-irradiation (10 Gy), IL-4 (5 ng/ml), or IL-4 plus $\gamma$ irradiation. The Cells $\left(5 \times 10^{5}\right.$ cells/well) were cultured for $24 \mathrm{~h}$, after which time the surface CD23 expression was measured by a FACSCalibur analysis. Each value represents a mean of duplicate samples.

regulation of IL-4-induced germline $\mathrm{C} \varepsilon$ transcription (Shen and Stavnezer, 1998; Koh et al., 2000). Furthermore, we have recently reported that IGF-1, which induces NF- $\kappa B$ activation and increases IL-4-mediated STAT6 activity, can potentiate CD23 gene activation and surface expression in tonsillar cells and Ramos B cells (Kim et al., 2003).

When B cells were stimulated with a suboptimal dose of IL-4, a substantial induction of CD23 expression was obtained as reported previously (Rousset et al., 1988; Kim et al., 2003). It was surprising that $\gamma$-IR alone induced a significant induction of CD23, and the combined treatment of IL- 4 and $\gamma$ IR resulted in a synergistic effect on CD23 induction of both mRNA and surface protein levels (Fig. 2A, B). The stimulatory effect of $\gamma$-IR on the NF- $\kappa B$ reporter activity in
IL-4-treated cells supports the concept that the augmentation of IL-4-induced CD23 gene expression by $\gamma$-IR is probably due to the ability of $\gamma$-IR to positively modulate NF- $\kappa B$ activation (Fig. 2C). In recent studies it has been reported that ionizing radiation also modulates STAT protein activation in certain cell types (Kulms and Schwartz, 1991; Aragane et al., 1997). Thus, the possibility that CD23 induction by $\gamma$-IR involves STAT6 activation was examined in these cells. Despite a relatively high basal level of STAT6 activity in these transformed cells, a treatment of IL-4 induced an additional increase in STAT6 activity, as shown by an increase in phosphotyrosine-STAT6 within 30 60 min (Fig. 3A). $\gamma$-IR, however, can not induce STAT6 activation (Fig. 3B), nor did it potentiate the STAT6 activity induced by IL-4 in these B cells, 
A

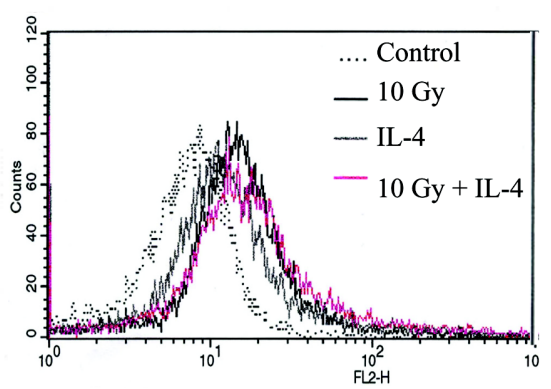

B
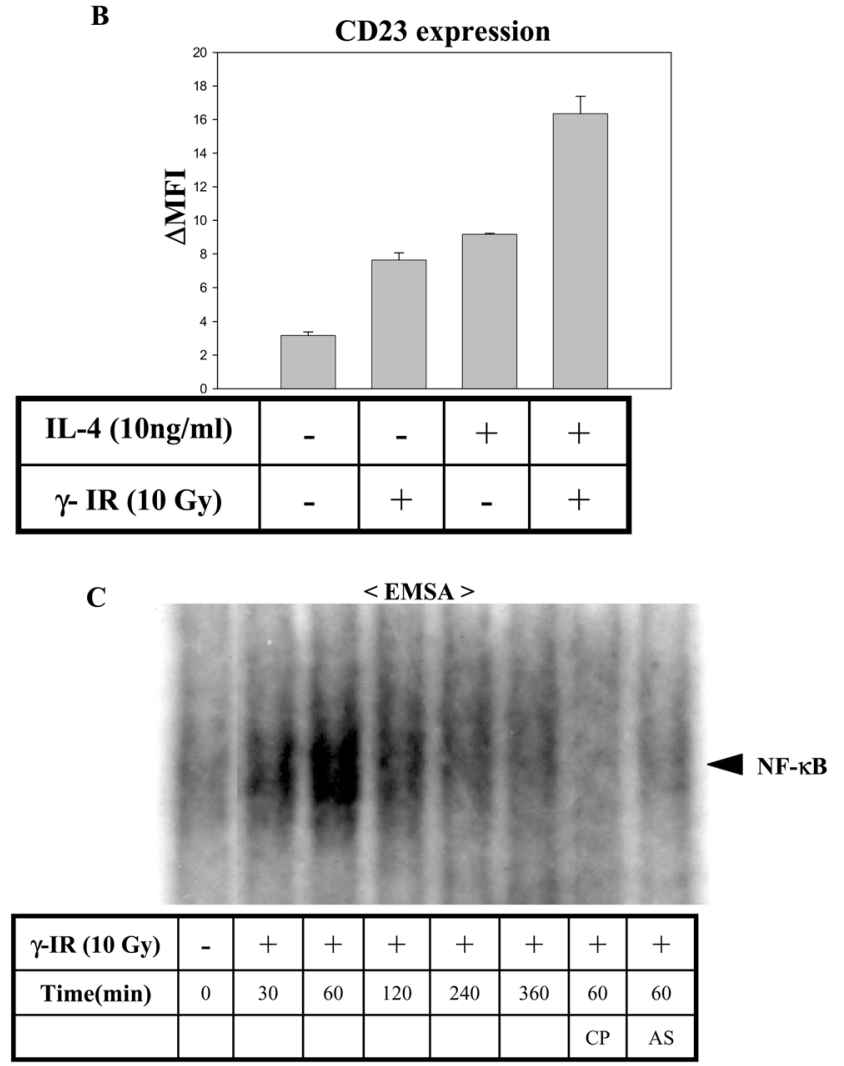

Fig. 6. The effect of $\gamma$-irradiation on the induction of NF- $\mathrm{KB}$ activity and CD23 expression in monocytic cells. A and B. U937 cells were treated with media alone, $\gamma$-irradiation (10 Gy), IL-4 $(10 \mathrm{ng} / \mathrm{ml})$, or IL-4 plus $\gamma$-irradiation. The cells were cultured for $24 \mathrm{~h}$, after which time the surface CD23 expression was measured by a FACSCalibur analysis. A: A representative FACScan histogram overlay; B: Relative fluorescence intensity. C. U937 cells were exposed to $10 \mathrm{~Gy}$ of $\gamma$-irradiation for various time periods as indicated. An EMSA was performed using nuclear extracts and the NF- $\kappa \mathrm{B}$ probe, as was done in Fig 1A.

under the conditions we employed (data not shown). The results indicate that induction of NF- $\mathrm{KB}$ activity by $\gamma$-IR, coupled with the high basal level of STAT6 activity, may lead to the up-regulation of CD23 expression in Ramos B cells, even in the absence of IL-4 treatment. In contrast, for primary immune cells such as the tonsillar mononuclear cells used in Fig. 2B, where basal STAT6 activity is generally low, the $\gamma$-IR treatment alone was not sufficient to induce CD23 mRNA, whereas the IL-4 treatment alone was able to do so. This further supports a prior idea that STAT6 is a primary factor for $\mathrm{CD} 23$ induction and that NF- $\mathrm{KB}$ plays an additive or synergistic role (Kim et al., 1997; Koh et al., 2000 ).

In order to further establish the role of NF- $\kappa B$ in the $\gamma$-IRinduced CD23 expression, we analyzed the effects of negative or positive regulators of NF- $\kappa \mathrm{B}$ activity on CD23 expression in B cells. As shown in Fig. 4, an anti-oxidant and a known NF-kB inhibitor PDTC (Schreck et al., 1992) substantially suppressed the $\gamma$-IR-induced CD23 expression (Fig. 4A). A similar effect was obtained with a proteosome inhibitor MG132, which also attenuated the $\gamma$-IR-induced NF- $\kappa B$ activation (Fig. 4B). Although the upstream signals that regulate the NF- $\kappa \mathrm{B}$ activity induced by $\gamma$-IR have not been well defined, we have found that the oncogenic Ras (V12 Ras) up-regulates the NF- $\kappa B$ activity induced by $\gamma$-IR in B cells, as was assessed by the nuclear NF- $\kappa \mathrm{B}$ levels and EMSA (Fig. 5A, B). It is important to note that Ras also up-regulated the $\gamma$ IR- or IL-4-induced CD23 expression (Fig. 5C). The results demonstrate that NF- $\kappa B$ modulating signals affect the $\gamma$-IRinduced CD23 expression in B cells, and this further supports the role of NF- $\kappa B$ induced by $\gamma$-IR in B cell differentiation. The enhancing effect of Ras on the IL-4-induced CD23 expression seems to be due to its ability to induce NF- $\kappa \mathrm{B}$ activation, and this works in synergy with IL-4-activated STAT6 for CD23 transcription, as suggested in previous studies (Shen and Stavneze, 1998; Koh et al., 2000).

The activation of NF- $\mathrm{KB}$ and the up-regulation of CD23 expression by $\gamma$-IR were also observed in U937 monocytic cells. The monocyte is another cell type that expresses CD23 and it participates in allergen presentation as well as allergic inflammation. As seen in the Ramos B cells, $\gamma$-IR also augmented the IL-4-induced CD23 levels in these monocytic cells (Fig. 6). Thus, the results from our present study, when considered together with our previous report on the immunomodulatory action of IGF-1 on CD23 up-regulation, mainly via $\mathrm{NF}-\kappa \mathrm{B}$ activation, suggest that various stress signals that induce NF- $\mathrm{BB}$ activation in immune cells can potentially modulate the specific gene expression involved in an allergic inflammation response. In fact, a number of genes involved in the allergic response possess an NF- $\kappa \mathrm{B}$ site in their promoters. Moreover, it should be noted that radiation stress tends to induce immune modulation leading to the suppression of Th1 cytokines and the stimulation of Th2 cytokines (El-Ghorr and Norval, 1997; Schmit et al., 2000). Thus, as discussed in a recent article (Dubben et al., 1997), $\gamma$ IR can potentially affect hypersensitivity and the allergic response, and these conditions may be further aggravated because of the co-stimulation by the cytokines present in the immune cell microenvironment.

Acknowledgment This study was supported by a research grant from MOPHW(02-PJ1-PG3-21202-0006). 


\section{References}

Aragane, Y., Kulms, D., Luger, T. A. and Schwarz, T. (1997) Down-regulation of interferon gamma-activated STAT1 by UV light. Proc. Natl. Acad. Sci. USA 94, 11490-11495.

Baldwin, A. S. Jr. (1996) The NF-KB and IאB proteins: New discoveries and insights. Annu. Rev. Immunol. 14, 649-681.

Berberich, I., Shu, G. L. and Clark, E. A. (1994) Cross-linking CD40 on B cells rapidly activates nuclear factor $k \mathrm{~B}$. $J$. Immunol. 153, 4357-4366.

Brach, M. A., Hass, R., Sherman, M. L., Gunji, H., Weichselbaum, R. and Kufe, D. (1991) Ionizing radation induces expression and binding activity of the nuclear factor кB. J. Clin. Invest. 88, 691-695.

Brennan, P. and O'Neill, L. A. (1995) Effects of oxidants and antioxidants on nuclear factor kappa B activation in three different cell lines: evidence against a universal hypothesis involving oxygen radicals. Biochim. Biophys. Acta. 1260, 167175.

Dubben, H. H., Roper, B. and Brackrock, S. (1997) Is there sufficient evidence of hypersensitivity to low dose in radiotherapy. Radiother. Oncol. 43, 324-325.

El-Ghorr, A. A. and Norval, M. (1997) The role of interleukin-4 in ultraviolet B-induced immunosuppression. Immunology 92, 26-32.

Finco, T. S., Westwick, J., Norris, J. L., Beg, A. A., Der, C. J. and Baldwi, A. S. Jr. (1997) Oncogenic Ha-Ras-induced signaling activates NF-kappaB transcriptional activity, which is required for cellular transformation. J. Biol. Chem. 272, 24113-24116.

Finkel, T. (1998) Oxygen radicals and signaling. Curr. Opin. Cell. Biol. 10, 248-253.

Flores-Romo, L., Shields, J., Humbert, Y., Graber, P., Aubry, J. P., Gauchat, J., Ayal, G., Allet, B., Chavez, M. and Bazin, H. (1993) Inhibition of an in vivo antigen-specific IgE response by antibodies to CD23. Science 261, 1038-1041.

Ghosh, S., May, M. J. and Kopp, E. B. (1998) NF-kappa B and Rel proteins: evolutionarily conserved mediators of immune responses. Annu. Rev. Immunol. 16, 225-260.

Hatada, E. N., Krappmann, D. and Scheidereit, C. (2000) NFkappaB and the innate immune response. Curr. Opin. Immunol. 12, 52-58.

Hou, J., Schindler, U., Henze, W. J., Ho, T. C., Brasseur, M. and McKnight, S. L. (1994) An interleukin-4-induced transcription factor: IL-4 Stat. Science 265, 1701-1706.

Jonathan, E. C., Bernhard, E. J. and McKenna, W. G. (1999) How does radiation kill cells? Curr. Opin. Chem. Biol. 3, 77-83.

Kari, M. and Lin, A. (2002) NF-KB at the crossroads of life and death. Nature Immunol. 3, 221-227.

Kasid, U., Suy, S., Den, P., Whitesid, T. L. and Sturgill, T. W. (1996) Activation of Raf by ionizing radiation. Nature 382, 813-816.

Kehry, M. R. and Yamashita, L. C. (1989) Low affinity IgE receptor (CD23) functions on mouse B cells: role in IgEdependent antigen focusing. Proc. Natl. Acad. Sci. USA 86, 7550-7560.

Kim, H. I., Park, H. J. and Lee, C. E. (1997) Intracellular signaling pathways for CD23 induction by IL-4 and anti-CD40 antibody. J. Biochem. Mol. Biol. 30, 431-437.

Kim, J. H., Park, H. H. and Lee, C. E. (2003) IGF-1 potentiation of IL-4-induced CD23/FceRII expression in human B cells.
Mol. Cells 15, 307-312.

Koh, H. J., Park, H. H. and Lee, C. E. (2000) Regulation of IgE and type II IgE receptor (CD23) expression by insulin-like growth factor-1: Role of Stat6 and NF-кB. J. Biochem. Mol. Biol. 33, 454-462.

Kulms, D. and Schwartz, T. (2001) Ultraviolet radiation inhibits IL-2-induced tyrosine phosphorylation and activation of Stat5 in T lymphocytes. J. Biol. Chem. 276, 12849-12855.

Lander, H. M. (1997) An essential role for free radicals and derived species in signal transduction. FASEB J. 11, 118-124.

Lee, S. W., Han, S. I., Kim, H. H. and Lee, Z. H. (2002) JAK-1dependent activation of AP-1 and JNK by receptor activator of NF-кB. J. Biochem. Mol. Biol. 35, 371-376.

Mikita, T., Campbell, D., Wu, P. G., Williamson, K. and Schindler, U. (1996) Require-ment for IL-4-induced gene expression and functional characterization of Stat6. Mol. Cell. Biol. 16, 5811-5818.

Mudde, G. C., Bheekha, R. and Bruijnzeel-Koomen, C. A. F. M. (1995) Consequence of IgE/CD23-mediated antigen presentation in allergy. Immunol. Today 16, 380-383.

Nakanish, K., Yoshida, N., Kishimoto, T. and Akira, S. (1996) Essential role of Stat6 in IL-4 signaling. Nature 380, 627-630.

Ozdener, F., Kunapuli, S. P. and Daniel, J. L. (2002) Expression of enzymatically-active phospholipase $\mathrm{Cr}_{2}$ in E. coli. J. Biochem. Mol. Biol. 35, 508-512.

Reddy, S. A., Huang, J. H. and Liao, W. S. (2000) Phosphatidylinositol 3-kinase as a mediator of TNF-induced NF-kappa B activation. J. Immunol. 164, 1355-1363.

Rousset, F. Malefijt, R. W., Slierendreg, B., Aubry, J. P., Bonnefoy, J. Y., Defrance, T., Banchereau, J. and de Vries, J. E. (1988) Regulation of Fc receptor for IgE (CD23) and class II MHC antigen expression on Burkitt's lymphoma cell lines by human IL-4 and IFN-gamma. J. Immunol. 140, 2625-2632.

Sakurai, H., Chiba, H., Miyoshi, H., Sugita, T. and Torium, W. (1999) IkappaB kinases phosphorylate NF-kappaB p65 subunit on serine 536 in the transactivation domain. J. Biol. Chem. 274, 30353-30356.

Sarfati, M. and Delespesse, G. (1988) Possible role of human lymphocyte receptor for IgE (CD23) or its soluble fragments in the in vitro synthesis of human IgE. J. Immunol. 141, 21952159.

Schmitz, M. L., Bacher, S. and Krach, M. (2001) IkappaBindependent control of NF-kappa B activity by modulatory phosphorylations. Trends Biochem Sci. 26, 186-190.

Schreck, R., Meier, B., Mannel, D. N., Dorge, W. and Baeuerle, P. A. (1992) Dithiocar-bomates as portent inhibitors of NF- $k$ B activation. J. Exp. Med. 175, 1181-1194.

Schreck, R., Rieber, P. and Baeuerle, P. A. (1991) Reactive oxygen intermediates as apparently widely used messengers in the activation of the NF-kappa B transcription factor and HIV-1. EMBO J. 10, 2247-2258.

Shen, C. H. and Stavnezer, J. (1998) Interaction of Stat6 and NF$k \mathrm{~B}$ : Direct association and synergistic activation of IL-4induced transcription. Mol. Cell. Biol. 18, 3395-3400.

So, E. Y., Jang, J. Y. and Lee, C. E. (2001) Cross-talk between STAT6 and Ras/MAPK pathway for the IL-4-mediated T cell survival. J. Biochem. Mol. Biol. 34, 578-583.

So, E. Y., Kim, S. H., Park, H. H., Cho, B. S. and Lee, C. E. (2002) Corticosteroid inhibits IL-4 signaling through downregulation of IL-4 receptor and Stat6 activity. FEBS Lett. 518, 
53-59.

So, E. Y., Park, H. H. and Lee, C. E. (2000) Interferon gamma and alpha down-regulate the IL-4-induced IL-4 receptor gene expression by post-transcriptional modulation. J. Immunol. 165,
$5472-5479$.

Zhu, C., Bogue, M. A. and Roth, D. B. (1996) Thymocyte differentiation in gamma-irradiated severe combined immunodeficient mice. Eur. J. Immunol. 26, 2859-2865. 